\title{
Factors influeincing health tourism development in Belokurikha Resort
}

\author{
Dunets A.N., Akimov O.S., Latysheva O.A. \\ Altai State University, Barnaul, Russia \\ https://orcid.org/0000-0002-3804-6800, https://orcid.org/0000-0001-9279-1943 \\ E-mail: dunets@mail.ru, akimovo@mail.ru,whitemails@mail.ru
}

Received: 11.08.2019 Accepted: 25.09.2019

\begin{abstract}
The paper studies approaches to understanding the health tourism in Belokurikha Resort. In fact, Belokurikha Resort is the largest recreational area in the Asian part of the Russian Federation. The authors define the factors of tourism development in the area and outline the elements of health tourism development: historical development, natural resources, economic, infrastructural, ethnosocial, tourist, administrative, informational and business ones. The paper considers an influence of these factors on sustainable development of Belokurikha Resort and its neighboring territories.
\end{abstract}

Key words: Health tourism; Development of factors, Belokurikha Resort, Health tourism development

\section{Introduction}

Currently, the health tourism development is based on the sanatorium and resort services. In fact, the health tourism development is one of the strategic directions of the tourist industry in Altai Krai. This type of tourism, unlike sanatorium-resort complex, can provide space resources and movements (travelling/hiking) during leisure hours to have a favorable therapeutic effect.

Medical tourism (MT) is a part of tourism activity that refers to people traveling to obtain medical treatment. It includes a range of medical diagnostic and clinical activities, rehabilitation, preventive and recreational services provided in some areas possessing necessary facilities, natural and human resources in order to offer the relevant treatment and rehabilitation. The development of Belokurikha Resort contributes to the tourist development of the neighboring territories and the emergence of the concept of "Bolshaya Belokurikha." This territory is located at the junction of the plain space of Western Siberia and the Altai Mountains. The area is characterized by low mountainous terrain and is located between the rivers Peschanaya and Poperechnaya. The mountainous part of the territory belongs to the Belokurikhinsky granite massif within the Cherginsky Ridge.

\section{Methods}

It should be noted that factors are internal causes that can affect the development of the tourism industry and recreation system, and conditions are external causes that do not determine the nature and properties of the system. Moreover, conditions create only a natural and socio-economic environment, and factors play an important role in the formation of tourist and recreational systems. Over time, the role of factors has changed and at present the study of the factors is significant.

Medical tourism is influenced by many factors that can contribute to or limit its development. V. Preobrazhensky (1975) divided factors into generating needs for creating a territorial recreational system and realizing the need. They can be territorially nonlocalizied and localizied, and their action is spatially differentiated. N. Mironenko and I. Tverdokhlebov (1981) identified groups of factors: socio-economic; factors associated with resources of natural and anthropogenic origins; infrastructure factors; geographical location factor. In addition, L. Mazhar suggested external and internal conditions / factors in relation to tourist entities (tourist and recreational systems). All factors of medical tourism development can be divided into basic (natural, socio-cultural, economic ones) and additional which are very essential for tourism industry development (entrepreneurship and information factors). Medical tourism as a type of business sector can have high profitability, but it also can make inadequate profits or even losses.

The information factor in tourism industry, as in many other business sectors, is essential. The form and quality of information determines the formation of a tourist image. While studying the factors of tourist centers development, it is also possible to use the four groups of factors proposed by $\mathrm{M}$. Porter, in particular, demand conditions, related and supporting industries, conditions of competition, and firm strategies. The first group of "factor conditions" can be divided into several groups: human resources (quantity, qualifications, labor costs, etc.); physical resources (resources related to natural resources); knowledge resource (information affecting goods and services); monetary resources (the amount and cost of capital that can be used in business; infrastructure (type, quality). Considering the factors of development of recreational nature management I. Yakovenko (2003) identifies six groups: natural, socio-cultural, demographic, economic, historical, environmental ones. The recreational demand of the population can be considered as a generating factor of the external and internal order, and natural and environmental factors are intra-systemic. Most factors can be characterized as dynamic, which explains the significant dynamism of the spatial forms of tourist and recreational activities.

In addition, V. Orlova and A. Shcherbakova define two groups of factors:

- Factors that can function regardless of the activity of medical establishments (political, economic, socio-demographic);

- Factors that can contribute to health tourism development, actively used by organizations in their activities (scientific, technical, organizational and technological, cultural and educational etc.) 
The influence of factors has macro-regional in nature and has an external effect on the region. Therefore, they can be identified as "conditions". For example, studying the factors of medical tourism development is determined by the socio-economic and political conditions, investment policy in the country. The features of the action of "conditions" are manifested at different levels of medical tourism organization.

\section{Results and Discussion}

There are a number of factors globally leading to the growth of medical tourism. These factors include the growth of the urban population, the increase of free time and income, mobility, the development of information technologies that allow people to obtain quickly relevant information about the natural and cultural resources of the regions. For tourist regions, the most important factors that either contribute to or limit the development of medical tourism are attractiveness, accessibility, and the tourist image.

The influence of the factors at different times can be strengthened or weakened. In this study we have distinguished the following groups of factors having impact on the organization of medical tourism: natural resource, economic factors, infrastructure, ethnosocial factors, tourist demand, historical factors, administrative factors, information factors, staffing, innovation and business initiatives. For example, natural resource factors determine the fundamentals of tourism development. They are natural tourist resources, primarily a combination of relief, climate, hydrography, flora and fauna, landscapes. Mineral waters, therapeutic muds, phytoncide properties of vegetation, medicinal herbs, livestock products (for example, deer breeding products) are of particular importance for medical tourism. The relief of the territory is characterized by a high degree of erosion due to the erosion activity of the Peschanaya River and its tributaries: the Belokurikha river, the Chernova river, and others. The rivers have a longitudinal profile and their transverse profile is $V$-shaped. The absolute elevations range from $450 \mathrm{~m}$ to $845 \mathrm{~m}$ and the relative elevations are $100 \mathrm{~m}$ or even more. The mountain slopes are mostly steep. The low mountainous terrain of the vicinity of Belokurikha is the most optima for medical tourism development. There is a network of paths and tourist routes. The most famous rocks are on Tserkovka Mountain. The top of the mountain is reminiscent of a dome and an orthodox cross was installed on a stone boulder there. The bizarre forms of the cliffs have interesting names: "Four Brothers", "Barns", "Gardeners", "Loaf", "China Wall".

Famous thermal radon waters are located in the Smolensk region: Belokurikhinskaya and Iskrovskaya. Nitrogen-silicon mineral waters come to the surface with a temperature of 37 and $42{ }^{\circ} \mathrm{C}$, they contain a small amount of radon $(0.2 \mathrm{kB} / \mathrm{I})$, a lot of gases (28 $\mathrm{mg} / \mathrm{I}$, of which $95 \%$ nitrogen, 0.54 radon, helium and also: argon, xenon, hydrogen sulfide) fluorine (14 mg / I), silicic acid (58 mg / I) and other elements. In fact, climate is a main factor for medical tourism development. This area is the low mountains of Altai and has the most favorable bio-climate in the region. Belokurikha Resort, located in the zone of foothills, low and middle mountains, has favorable conditions for the formation of a buffer layer of warm air in the cold season. So, the region has less severe winters and longer frost-free periods. The average air temperature in January in Belokurikha is $-16.8^{\circ} \mathrm{C}$, while in Biysk, $75 \mathrm{~km}$ to the north, it is $18.2^{\circ} \mathrm{C}$, and in the mountainous part of Altai it is $-17.5^{\circ} \mathrm{C}$. At the same time, in hot anticyclonal weather within the region there is a slight decrease in average temperatures compared with the plain, steppe spaces of the region.

The territory of "Bolshaya Belokurikha" belongs to the areas that are especially favorable for resort and recreational activities possessing relevant bioclimatic resources. The vegetation cover of "Bolshaya Belokurikha" is rich and diverse. It has features of the steppe, forest and mountain areas located on the border of flat and mountainous landscapes. Steppe areas are widely involved in agriculture industry- crops, pastures, hayfields.

Economic factors are characterized by the structure of the economy in the region and the level of the local population life. In fact, Belokurikha is a year-round resort. Therefore, the spa sector is the basis of the local economy. For example, investments in fixed assets of enterprises have increased from 244 million rubles in 2012 to 432 million rubles in 2018. Agricultural enterprises have an impact on a structure of the local economy. The enterprises manufacture and provide the resort with the necessary products: meat, milk and dairy products, vegetables.

According to the data of the Federal State Statistics Service (Rosstat) the standard of living of the population of Altai Krai is lower in comparison with other regions of the Russian Federation. Moreover, the situation has not changed for many years. However, in Belokurikha Resort the standard of living is higher than in most municipal regions of the region.

Infrastructural factors are transport routes, accommodation facilities, food and entertainment facilities. Currently, the main road of the region is a Biysk - Belokurikha road and it is in good condition. In the frame of the project the Belokurikha 2 a transport and engineering infrastructure has been built. The new highway from Belokurikha Resort leads to the mountainous part of Belokurikha, opening up opportunities for the construction of new tourist facilities and routes. It should be noted that there is the Altai - Rossosh Starobelokurikha - Novotyryshkino - Sychevka - Solonovka road along the northern border of the mountains. In addition, tourists can use dirt roads and roads with improved coverage: Krasny Gorodok - Chernovaya - Iskrovskoye mineral water deposit - the city of Belokurikha - Danilovka - Makaryevka. In the narrow valleys, at the exit to the plain tourist facilities are being constructed. There is Altai-Nikolskoye-Kuyagan-Kuyacha highway in the eastern and southern parts of the Belokurikhinsky granite massif. The western conditional border of "Bolshaya Belokurikha" possesses the Solonovka-Berezovka-Soloneshnoe highway.

Belokurikha is a center for providing tourist services in Belokurikha Resort. Currently, the main transport network with tourist attractions is being built: Belokurikha 2, Belokurikha mine - Belokurikha 3 (Osinovka). One of the main purposes is to construct a bridge across the river Peschanaya and a part of the road between the villages of Osinovka and Sosnovka.

Analyzing the changes in accommodation facilities over the past few years, there is a slight increase of the number of sanato riums. According to the survey of the Tourism Department of Altai Krai, there were 13 hotels and 13 resorts in 2012 , and in $2018-23$ hotels and 14 resorts. However, the infrastructure of accommodation facilities has significantly changed. There are more hotels that can be assessed as three or four - stars hotels.

Belokurikha Resort is located in a narrow mountain valley. There is a concentration of tourist facilities and land scarcity here. Therefore, new objects have been created on the neighboring territories for some years.

Ethno-social factor characterizes the size and structure of the population, national composition, migration, urbanization process. The population of Belokurikha is about 15 thousand people. The resort is surrounded by rural areas. The nearest city is Biysk and it is located $60 \mathrm{~km}$ from the resort. It is an industrial center and has an impact on the surrounding rural areas. In fact, Biysk and Belokurikha determine migration patterns of local population. So, immigrants from different regions of Russia, as well as Ukrainians, Germans, Belarusians, live in the resort and neighboring territories.

Tourism demand factors define domestic and international tourism needs. Currently, about 250 thousand people visit Belokurikha Resort. Tourists are mostly residents of Siberian regions (Novosibirsk, Tomsk, Tyumen, Kemerovo regions, Krasnoyarsk Territory). In recent years, there has been an increase of the number of tourists visiting Belokurikha to receive treatment and have a rest.

Factors of the historical development of tourism industry are determined by the duration, intensity and stages of tourist development of the territory. 
The warm springs of Belokurikha were first tested by peasants E. Gudkov and S. Kazantsev. In 1866, they informed a famous scientist and state adviser S. I. Gulyaev, who lived in Barnaul, about positive influence of warm mineral water.

S. I. Gulyaev collected material about geography, ethnography and the history of the region. It is noted that he supported the building of the first bath.

In 1868, a hut bathhouse was built, which housed 17 baths. In 1916, the Biysk Division of the Society for Assisting the Sick and Wounded Warriors built a building possessing 8 baths and a sanatorium for 325 patients. Since 1932, patients began visiting the sanatorium in the winter, and the number of places increased to over 400, while the capacity exceeded 5,000 people a year.

Since 1967, a new stage in the formation of the resort began. New sanatoriums "Tsentrsoyuz", "Altai", "Katun", "Russia", "Siberia", children's sanatoriums of the Ministry of Health of the RSFSR and the regional health center, a polyclinic for radiation therapy (80 baths), "Rodnik ZapSiba", a sanatorium "Gornyak" were built. By the beginning of economic transformations in Russia, Altai Krai was one of the most popular tourist regions of the Soviet Union. Annually, more than 50 thousand people received treatment and rehabilitation courses in the sanatoriums of Belokurikha Resort. However, with the beginning of the political and economic reforms, the industry based on the trade unions practically disappeared and new forms of development of sanatoriums were considered for many years.

In the early 1990s in Altai Krai, a concept of the South Altai Ecological and Economic Region was developed. This territory included the southern low-mountain and foothill areas of Altai Krai. The main purpose of this concept was to preserve the unique natural complex of Altai foothills, to manufacture organic products and to develop tourist and recreational activities. Belokurikha Resort played an important role in the tourism development. Since then within the framework of the concept of the formation of the South Altai Ecological and Economic Region, a program was developed for the development of the Belokurikha as a medical and recreational area (BLOM).

In 2006-2010 social and economic development programs and spatial planning schemes were carried out. In this regard, an emphasis was placed on sustainable development of Belokurikha Resort as a major tourist center of the state. Moreover, the development of tourist infrastructure was planned in neighboring territories.

These projects and programs were the fundamentals for development of the Altai resort and recreational area at the beginning of $21^{\text {st }}$ century. In 2007 the Altai Krai presented a new idea for the development of the resort at the international forum "MIPIM-2007". In addition, in 2010, architectural and planning proposals were carried out for the formation of the Belokurikha tourist and recreational cluster, and the construction of the Belokurikha Project 2 began.

Administrative and administrative factors are associated with the regulatory framework, structure and nature of the administrative management of tourist and recreational activities of the territory. Local authorities have always paid much attention to the resort. Belokurikha was included in the federal target program "Development of Domestic and Inbound Tourism in the Russian Federation (2011 - 2018)." Government bodies participated in creating "Altai Research Institute of Medicine and Health Tourism". This institute has become a center for sanatoriums to develop new treatment programs.

The information factor associated with the tourist image of the resort has a positive effect. For many years Belokurikha Resort has been recognized as the best resort in the Russian Federation. It should be noted that Altai Krai is associated primarily with the high mountains and Belokurikha Resort. Tourists can find relevant information about various options, services and wellness programs on the Internet. Organizing various scientific conferences, forums and festivals has also a positive effect. Also, business tourism plays a significant role in providing information and improving the image of the resort.

The staff factor is the availability of specialized personnel, the quality of student training, advanced training, labor resources. Personnel training is mainly carried out by Altai State Medical University, Altai State University, and Altai Academy of Hospitality. However, there is a problem of staff shortage, both medical workers and specialists involved in the provision of tourist services.

The factors of innovation and business initiatives have a special impact on the development of medical tourism. These factors are also associated with the creation of various tourist and recreational programs. Business initiatives launched the projects such as tourist and recreational complexes "Sibirskoje Podvorye", "Lesnyay Skazka", "Belokurikha 2" and "Belokurikha 3". In Russia, Iongterm treatment program (up to 21 days) are traditional for sanatoriums. These programs are licensed and any sanatoria do not have a right to use other programs. However, at present, most potential consumers do not have much time to relax and spend many days in the resort. So, the sanatoriums in Belokurikha united and used their financial resources to attract scientists in order to develop and substantiate short treatment programs. Currently, the Altai Institute of Balneology (a branch of the SibFNCC FMBA of the Russian Federation) in Belokurikha is developing health-improvement methods for three-ten day trips.

Health resort tourism routes are being developed in the sanatoriums, and they are connected with innovations in IT technologies. So, the fitness bracelets can indicate certain parameters of the body. They are used to control the health status of the tourist while he/she is hiking. Also, the use of daily (Holter) monitoring of ECG and blood pressure allows a doctor to monitor the state of human health. The next stage in the development of health tourism is the creation of medical health routes, and the possibility of transferring data from a tourist' fitness bracelets to a doctor's computer.

\section{Conclusion}

Thus, the study of tourism development factors is a significant component in the analysis of tourist territories. We have identified that the mentioned factors influence medical tourism significantly. In our study we used "Bolshaya Belokurikha" area as an example where all factors are represented. It is necessary to outline the strengthening of the mutual influence of all factors. The presence of natural resources does not always result in economic success of the territory and efficient development of medical and health tourism. Undoubtedly, a mixture of favorable factors, both natural and socio-economic ones, can determine the sustainable development of Belokurikha Resort.

\section{Acknowledgements}

The reported study was funded by RFBR, project number 19-45-220009 p_a

\section{References}

Bengardt, A. A. Ostapov, A. D. (2000). Resort Belokurikha. Altai Printing Plant (in Russian).

Dunets, A. N. (2007). The geography of tourism in Russia. Barnaul: Publishing house Altai State University (in Russian).

Golubev, P.A. (1890). Altai. Historical and statistical collection on the issues of economic and civil development of the Altai mountain district. Tomsk, Printing house of Mikhailov and Makushin (in Russian).

Mazhar, L. Yu. (2008). Territorial tourist and recreational systems. Smolensk, Universum, 211. (in Russian). 
Messerli, B., Ives, J.D., Yu.P. Badenkov, Kotlyakov, V.M. (1999). Mountains of the world. Global priority. Moscow, Publishing House Noosphere (in Russian).

Mironenko, N. S., Tverdokhlebov, I. T. (1981). Recreational Geography, Moscow, Moscow University Press (in Russian).

Orlova, V.S., Scherbakova, A.A. (2014). Prospects for the development of health tourism in the region. 4 (72), 34-45. (in Russian).

Porter, M. E. (2005). Competition. Moscow, Williams Publishing House (in Russian).

Preobrazhensky, V. S., Vedenin, Yu. A., Zorin, I. V. (1975). Theoretical Foundations of Recreational Geography. Moscow, Science, 224. (in Russian).

Revyakin, V. S., Pomorov, S. B., Vdovin, N. F. (1997). Belokurikha medical and recreational area. Barnaul, NIIGP Publishing House, (in Russian).

Sukhova, M.G. (2009). Bioclimatic conditions of human life in the Altai-Sayan mountain country. Tomsk, Tomsk University Press (in Russian).

Vetitnev, A.M. (2012). Health tourism: issues of terminology and typology. Vestnik SGUTiKD, 2(20), $50-56$ (in Russian).

Yakovenko, I. M. (2003). Recreational nature management: research methodology and methodology. Simferopol, Publishing House Tavria (in Russian).

\section{Citation:}

A.N.Dunets, O.S.Akimov (2019). Factors That Influence Health Tourism Development: Belokurikha Resort . Ukrainian Journal of Ecology, 9(3), 352-355. 